31. Topchiy Yu. S., Khabirov D. M. Modifitsirovannyy belkovyy plastifikator dlya tsementnykh sistem // Tekhnologii betonov. 2013. Vol. 11 (88). P. 46-47.

32. Ruzhitskaya A. V., Potapova E. N. Vliyanie dobavok-plastifikatorov na svoystva belogo portlandtsementa // Innovatsionnaya nauka. Tekhnika i tekhnologiya silikatov. 2009. Vol. 16, No. 1. P. 14-23.

33. Suraev V. Gidrofobizatsiya. Teoriya i praktika // Tekhnologi stroitel'stva. 2002. Vol. 1. P. 120-121.

34. Pashhenko A. A. Gidrofobizatsiya. Kyiv: Naukova dumka, 1973 $174 \mathrm{p}$.

35. Pashhenko A. A. Kremniyorganicheskie gidrofobizatory v stroitel'stve. Alma-Ata: Kazakhstan, 1968. 78 p.

36. Lukinskiy O. A. Gidrofobizatsiya zdaniy // Zhilishhnoe stroitel'stvo. 2008. Vol. 11. P. 21-23.

37. Sposoby otsenki vliyaniya poverkhnostnoy gidrofobizatsii betona i modifitsiruyushhikh ego strukturu dobavok / Orentlikher L. P. et al. // Beton i zhelezobeton. 1991. Vol. 2, No. 431. P. 28-30.

38. Gurinovich L. S., Usov B. A. The mechanochemical treatment of the building materials // Ecology and construction. 2015 Vol. 3. P. 22-25.

39. Demyanova V. S. Aktivnost' portlandtsementov v prisutstvi plastifikatora // Zhilishhnoe stroitel'stvo. 2000. Vol. 11. P. 30

40. Superplastifikatory $\mathrm{v}$ tekhnologii izgotovleniya kompozitsionnogo betona / Kamalova Z. A. et al. // Vestnik Kazanskogo tekhnologicheskogo universiteta. 2013. Vol. 8. P. 148-152.

41. Kalashnikov V. I. Terminologiva nauki o betonakh novogo pokoleniya // Stroitel'nye materialy. 2011. Vol. 3. P. 103-106.

42. Bazhenov Yu. M., Demyanova V. S., Kalashnikov V. I. Modifitsirovannye vysokoprochnye betony. Moscow: Assotsiatsiya stroitel'nykh vuzov, 2006. 368 p.

43. Strokova V. V. Molovieva L. N. Otsenka vliyaniya kristallicheskikh zatravok na strukturoobrazovanie tsementnogo kamnya // Stroitel'nye materialy. 2009. Vol. 3. P. 97-98.

44. Rashkovskiy A. S., Slutskiy N. G. Optimizatsiya sostava betona dlya pontonov kompozitnykh plavuchikh dokov // Zbirnik naukovikh prats' NUK. 2008. Vol. 5 (422). P. 17-24.
ИСЛОЛЬЗОВАНИЕ ВЫСОКОЗФФЕКТИВНЫХ ПЛАСТИФИКАТОРОВ С ЦЕЛЬЮ ОБЕСПЕЧЕНИЯ ПРОЕКТНЫХ И ЭКСПЛУАТАЦИОННЫХ ТРЕБОВАНИЙ К СОСТАВУ БЕТОНА ДЛЯ ПОСТРОЙКИ ПЛАВУЧИХ комПОЗИТНЫХ дОКОВ

Рассмотрены особые требования, которые предъявляются к судостроительному бетону и бетонной смеси в связи с экстремальными условиями работы морских железобетонных сооружений. Приведена классификация пластифицирующих добавок по эффективности пластифицирующего действия. Рассмотрено допустимое содержание вредных примесей в заполнителях для тяжелых бетонов. Приведены условия обеспечения трещиностойкости бетона. Проведенные исследования позволяют определить рекомендуемый гранулометрический состав песка и щебня, которые используются для судостроительного бетона

Ключевые слова: плавучий композитный док, судостроительный бетон, пластифицирующие добавки, суперпластификаторы, прочность бетона.

Kyrychenko Kostiantyn, Postgraduate Student, Department of Construction and Ship Repair, Admiral Makarov National University of Shipbuilding, Mykolaiv, Ukraine,e-mail: kostiantynkyrychenko@nuos.edu.ua, ORCID: http://orcid.org/0000-0002-0974-6904

Shchedrolosiev Oleksandr, Doctor of Technical Sciences, Professor, Head of the Department of Construction and Ship Repair, Admiral Makarov National University of Shipbuilding, Mykolaiv, Ukraine,e-mail: aleksandr.schedrolosev@nuos.edu.ua,ORCID:http:// orcid.org/0000-0001-7972-3882

Rashkovskyi Oleksandr, Doctor of Technical Sciences, Professor, Department of Construction and Ship Repair, Admiral Makarov National University of Shipbuilding, Mykolaiv, Ukraine, e-mail: olexandr.rashkovskyi@nuos.edu.ua,ORCID: https://orcid.org/00000002-3730-3748

\section{Karakurkchi A. Sakhnenko N., Ved M., Parsadanov I.}

\title{
RESEARCH OF THE PECULIARITIES OF PLASMA-ELECTROLYTIC TREATMENT OF AK12M2MGN PISTON ALIOY WITH FORMATION OF CERAMIC-LIKE COATINGS
}

Досліджено особливості плазмово-електролітичної обробки (ПЕО) поршневого силуміну АК12М2МгН у лужних електролітах з формуванням допованих манганом та кобальтом керамікоподібних покривів. Показано, що морфологія та склад оксидних покривів залежать від типу використовуваного електроліту. Визначено технологічні параметри ПЕО-обробки поршневого силуміну для формування рівномірних покривів із високим вмістом допантів. Запропоновані системи можуть знайти застосування в технологіях внутрішньоциліндрового каталізу з метою зниження токсичності газових викидів двигунів та підвищення іх паливної економічності.

Ключові слова: поршневий сплав АК12М2МгН, плазмово-електролітичне оксидування, поршневий силумін, керамікоподібний покрив.

\section{Introduction}

The internal combustion engine (ICE) piston is one of the most important details of a modern car that operates under severe conditions with significant thermal and mechanical loads. Therefore, the following requirements are put forward to piston alloys' properties: lightness, strength, low friction coefficient, high thermal conductivity, wear and corrosion resistance, economic accessibility and simplicity of technological treatment [1].

Alloys of aluminum with silicon (silumines) fully meet these requirements. The high content of silicon gives 
improved casting properties silumin, it allows increasing fatigue strength and reducing the coefficient of linear expansion. Also various alloying components are introduced in the composition of silumin, to provide higher corrosion resistance, mechanical strength and wear resistance.

At the same time, piston $\mathrm{Al}-\mathrm{Si}$ alloys produced in the EU countries and USA have much better performance characteristics. This is due to the narrowing of the variation intervals of the main components of the alloy, a lower content of undesirable impurities and the use of expensive modifiers (vanadium, zirconium, phosphorus) [2]. However, the production of such materials is highly technological and more valuable, which increases the cost of the final product.

A more rational approach to improving performance is the modification of the working surface of parts of the ICE piston group by applying coatings of various functional purposes. Their formation is carried out by electrochemical treatment of parts with deposition of galvanic coating [3], laser doping (surfacing) [4], deposition from the gas phase [5], and plasma and plasma-arc spraying [6].

However, these technologies are not widely distributed due to significant cost of sales and technological complexity. Therefore, it is important to find economically and technologically accessible ways of surface modification of internal combustion engine parts made of silumin to improve their operational properties [7].

One of the approaches is ceramic like coatings formation on the surface of the details by plasma electrolytic oxidizing (PEO) method [8].

The method is oxidizing the surface in aqueous electrolytes solutions at high voltage under the action of short-lived electric discharges. In such high-energy modes, a highly developed oxide matrix metal substrate with incorporated cations or the remelting electrolyte components forms due to the realization of electrochemical and thermochemical reactions $[9,10]$. Advantages of this method of surface modification is the simplicity of the process equipment, the nontoxicity of working solutions, the lack of a preliminary preparation of the part, the possibility of efficient treatment of complex-shaped and large-sized products.

The listed factors characterize the process of PEO treatment as economic, ecological and resource-saving. The change in oxidation conditions and the composition of working solutions makes it possible to form coatings of a given composition and properties.

\section{The object of research and its technological audit}

The object of research is the processes of treatment of the AK12M2MgN piston alloy treatment by the method of plasma electrolytic oxidation with the formation of ceramic like coatings.

One of the most problematic areas of this study is the effect of the chemical composition of the Al-Si alloy on the treatment and formation of ceramic like coatings. This is due to the peculiarities of the silumin microstructure including a significant number of alloying components and intermetallic compounds, which differ in the chemical properties and electrical conductivity of the oxides. At the same time, eutectics and primary precipitates of silicon in the alloy structure cause considerable embrittlement of the material [11].
To establish the regularities of the influence of silicon content in aluminum alloys on the process of PEO piston alloys treatment, a technological audit was carried out to study the processes of PEO treatment and the formation of ceramic-like coatings on piston silumin.

As a result of the audit, it is established that electrochemical technologies are widely used to modify the silumin surface by forming coatings of different composition and purpose $[12,13]$. PEO of such materials has certain characteristics in comparison with the oxidation of other aluminum alloys.

PEO piston silumins expediently carry out in alkaline complex electrolytes. This is for homogenization of the surface during treatment and to ensure high adhesion of the oxide coating to the substrate. Electrolytes of this type are characterized by high stability and convenience of adjustment during operation. At the same time, oxidation in such solutions allows the formation of ceramic like oxide coatings doped with various components [14, 15]. Electrolyte suspensions based on a homogeneous solution with additives of powders of various nature and dispersion degree can also be used [16, 17]. In this case, the coating formation occurs due to the mechanical capture of particles from the working solution in addition to electrochemical and thermochemical transformations. However, such electrolytes are less stable.

In the composition of surface oxide layers, compounds of transition, noble, rare and dispersed metals, some nonmetals, can be incorporated. The dopants' nature will influence the physical and mechanical properties of the formed ceramic-like coatings $[12,18]$. The introduction of catalytic components into the composition of the oxide coating of the piston group of internal combustion engines allows realizing the process of fuel catalytic combustion with increasing fuel efficiency and reducing toxic gas emissions [19, 20].

For plasma-electrolytic treatment of alloy model samples, a unit (Fig. 1) was used. The laboratory system includes a current source, an electrolytic cell with cooling and stirring of electrolyte, working electrodes and devices for monitoring process operating parameters.

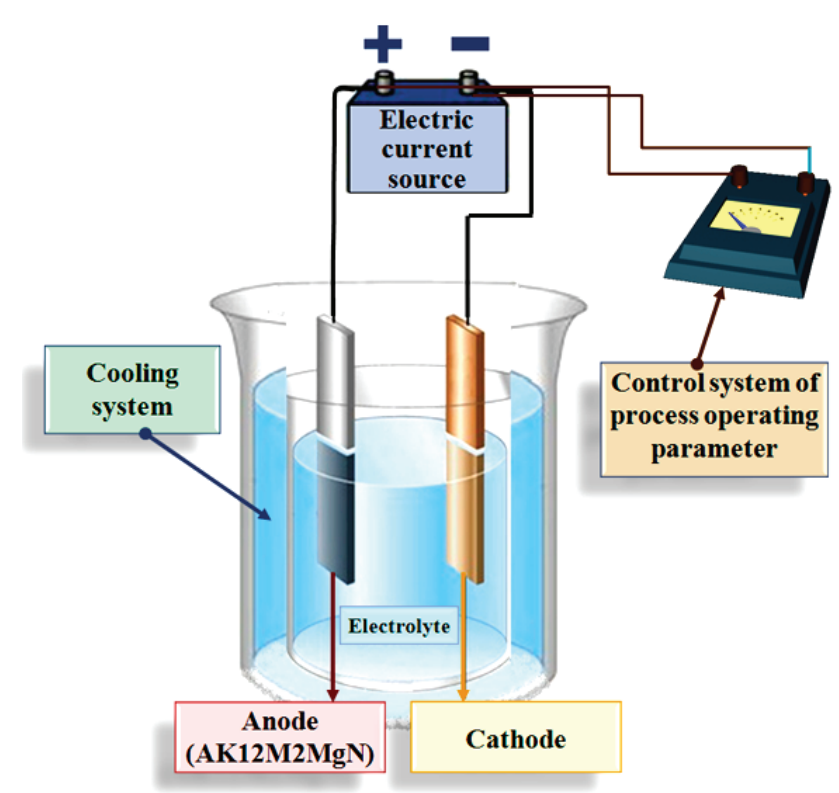

Fig. 1. Schematic representation of a laboratory unit for plasma-electrolytic treatment of model samples 
Modified unit with the same components (Fig. 2) with increased power to ensure the implementation of technological process parameter was used for the PEO of ICE piston.

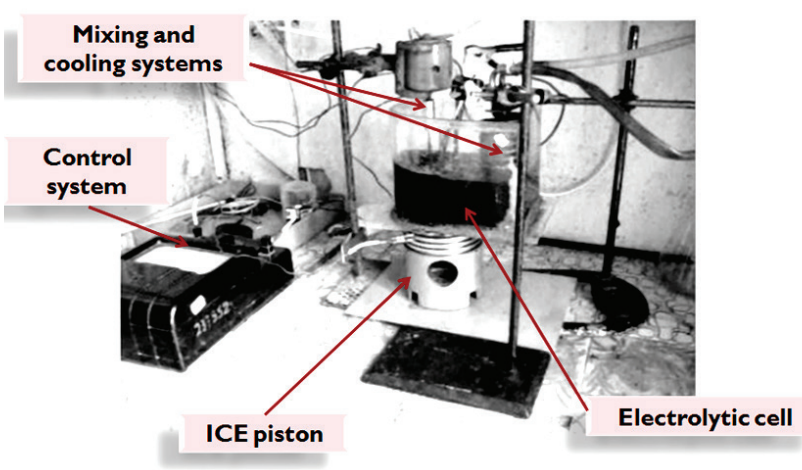

Fig. 2. Laboratory unit for plasma-electrolytic treatment of the piston of an internal combustion engine

Samples of silumin AK12M2MgN and piston KamAZ 740 were used for the studies. The chemical composition of the piston alloy is given in Table 1 .

Table 1

The chemical composition of the alloy AK12M2MgN (GO5T 1583), \%

\begin{tabular}{|c|c|c|c|c|c|c|}
\hline $\mathrm{Al}$ & $\mathrm{Si}$ & $\mathrm{Mn}$ & $\mathrm{Mg}$ & $\mathrm{Ni}$ & $\mathrm{Fe}$ & Сг \\
\hline $79.5-85.55$ & $11-13$ & $0.3-0.6$ & $0.8-1.3$ & $0.8-1.3$ & up to 0.8 & up to 0.2 \\
\hline $\mathrm{Ti}$ & $\mathrm{Cu}$ & $\mathrm{Pb}$ & $\mathrm{Zn}$ & 5n & Impurities \\
\hline $0.05-0.2$ & $1.5-3.0$ & up to 0.1 & up to 0.5 & up to 0.02 & total 1.3 \\
\hline
\end{tabular}

PEO was carried out in the working electrolytes shown in Table 2. Working solutions for research were prepared using certified «chemically pure» reagents and distilled water. The use of alkaline solutions with a content of transition metal salts makes it possible to efficiently conduct PEO treatment of valve metals and form oxide coatings with a significant content of dopant [10, 18].

Table 2

The composition of electrolytes for plasma-electrolytic treatment of a piston alloy

\begin{tabular}{|c|c|c|c|c|}
\hline $\begin{array}{c}\text { No. } \\
\text { of electro- } \\
\text { lyte }\end{array}$ & $\begin{array}{c}\text { Doping } \\
\text { component }\end{array}$ & $\begin{array}{c}\text { Electralyte } \\
\text { composition }\end{array}$ & $\begin{array}{l}\text { Concentration } \\
\text { of components, } \\
\mathrm{mol} / \mathrm{dm}^{3}\end{array}$ & $\begin{array}{c}\text { Electrolyte } \\
\text { temperature, } \\
{ }^{\circ} \mathrm{C}\end{array}$ \\
\hline \multirow{2}{*}{1} & \multirow{2}{*}{ Сo } & $\mathrm{CoSO}_{4}$ & 0.1 & \multirow{4}{*}{$20 \ldots .25$} \\
\hline & & $\mathrm{K}_{4} \mathrm{P}_{2} \mathrm{O}_{7}$ & 0.4 & \\
\hline \multirow{2}{*}{2} & \multirow{2}{*}{$\mathrm{Mn}$} & $\mathrm{KMnO}_{4}$ & 0.005 & \\
\hline & & $\mathrm{KOH}$ & 0.05 & \\
\hline
\end{tabular}

Oxidation was performed in galvanostatic mode using a stabilized DC source 55-50 (Ukraine). The treatment voltage was $160-240 \mathrm{~V}$, the current density was $3 \ldots 25 \mathrm{~A} / \mathrm{dm}^{2}$. Oxidation time was 30 minutes. Selected technological parameters are optimal for the formation of doped cobalt and manganese ceramic like coatings [21, 22].

Surface preparation of the samples included machining, degreasing and washing with water.

\section{The aim and objectives of research}

The aim of research is improvement of the treatment of piston made of silumin AK12M2MgN by the method of plasma electrolytic oxidizing producing doped cobalt and manganese ceramic like coatings.

To achieve this aim, it is necessary to solve the following tasks:

1. To determine the technological features of plasmaelectrolytic treatment of piston silumin AK12M2MgN in alkaline electrolytes of various composition.

2. To investigate the effect of doping metals on the morphology of the surface and the composition of the formed oxide layers.

3. To develop the technology of PEO treatment of the internal combustion engine piston producing the ceramic like coating of the combustion chamber.

4. To investigate the catalytic activity of the obtained coating during the piston bench tests.

\section{Research of existing solutions of the problem}

Investigation of the processes of directional modification of the surface of high-siliceous silumines due to the formation of oxide PEO coatings is a promising practical task. The silicon content affects the the PEO stages progress [22]. Oxidation conditions, the type of working electrolyte, and the nature of the doping components determine the composition and properties of the formed ceramic like systems [10].

In [23], PEO samples of an Al-Si alloy with a silicon content of $27-32$ wt. \% is performed in alkaline silicate electrolyte. The authors found that in the process of oxidation in the spark and micro-arc regions, the glow of discharges occurs predominantly at the boundaries of $\mathrm{Si}$ inclusions. As a result, the formation of a coating over the sample surface is inhibited; the formed oxide layer is uneven. The morphology of the formed surface is characterized by the presence of large dendrites of silicon oxide. To obtain uniform oxide coatings, the treatment time of the alloy samples should be at least 60 minutes.

Similar patterns were revealed by the authors of [24] when studying the PEO process of a cast Al-Si piston alloy with a silicon content of 12 wt. \%. To optimize PEO treatment, researchers used a silicate electrolyte with sodium phosphate additives. It has been established that silicon particles in the composition of the alloy and eutectic Si phases inhibit the oxidation of aluminum and affect the composition and morphology of the resulting coatings.

It is noted in [25] that the silicate content in the working electrolyte affects the duration of the PEO treatment of high-silica alloys of aluminum, the composition and thickness of the formed oxide coatings. This makes it possible to control the technological process of plasmaelectrolytic treatment of silumin by varying the concentration of the components of the working solution.

Formed in silicate electrolytes PEO coatings for silumin have increased microhardness and corrosion resistance in comparison with the untreated surface [26, 27]. However, through a significant content of silicon in the surface layers, these parameters are not optimal.

To expand the spectrum of functional properties, in particular PEO coatings on silumin, it is advisable to use 
complex electrolytes and introduce additional components into the coating composition. In particular, the incorporation of transition metal oxides exerts an oxidized surface of aluminum alloys with catalytic activity [19, 21].

The author of [28] used aluminum silicate electrolytes with additions of sodium tetraborate, trilon B, acetic acid and transition metal acetates to obtain oxide coatings on aluminum alloy A1050. The coatings were formed by alternating current at an average density of $100 \mathrm{~mA} / \mathrm{cm}^{2}$. Under these conditions, uniform oxide layers obtained with a dopant content of 1.11-5.43 at. \%. At the same time, the coatings contain 8.46-13.5 at \% of Si and 8.06-32.62 at \% of carbon, which is explained by the thermolysis of the electrolyte components with PEO.

In [29] doped with magnesium, manganese and zinc oxide coatings for the alloy AD1 were formed from polyphosphate electrolytes. It is established that the content of the admissible elements in the coating is proportional to the ratio of the concentrations of polyphosphates and the metal salt in the solution. The phase composition of the obtained oxide layers varies with the time of the PEO and the component composition of the working solution.

Polyphosphate electrolytes were also used to produce oxide coatings on an aluminum alloy AMnM with a high content of dopant [30]. It is shown that the formation of polyphosphate complexes with doping metals promotes their uniform incorporation into oxide films.

Thus, from the point of view of the effectiveness of the surface modification of silumin, it is advisable to use for their treatment electrolytes based on complex compounds, in particular polyphosphates. In the oxidation process, this allows homogenizing the composition of alloy surface layer, reducing the content of alloying components and creating conditions for the formation of a uniform oxide coating and the dopants incorporation.

Oxidation of samples of piston alloys allows developing the technology of surface PEO treatment of the engine piston group as a whole. Most researchers use silicate electrolytes. In these solutions, oxide coatings with increased heat-shielding properties are formed.

The authors of [31] presented the results of studies on PEO technology usage to strengthen the working surfaces of the engine cylinder assembly. The technological possibility of realizing PEO for large-sized silumin moldings producing a high-quality oxide layer is shown.

The paper [32] is devoted to the study of the feasibility and prospects of using PEO technology for repairing and restoring the geometry of the working surfaces of engine parts from silumin with a silicon content of 4-15\%.

In work [33], the process of PEO treatment of a regular piston engine АПД-800 made from the alloy AK12D was used to obtain a heat-shielding oxide layer. Oxidation was carried out for 1.5 hours in an alkaline-silicate electrolyte. As a result of the studies, a decrease in the thermal stress of the piston with a PEO coating applied during the operation of the engine was established.

The authors of [34] give the results of experimental studies on strengthening the ASP80 piston surface from the AK12 alloy by the PEO method in alkali-silicate electrolyte. The wear rate of the piston with the applied coating is reduced by 2.5 times with bench tests.

The authors [35, 36] established a decrease in the road and transport fuel consumption by $5-7 \%$ when using
PEO coatings on the ICE pistons in comparison with conventional engine pistons.

The authors of $[37,38]$ experimentally confirmed the increase in the efficiency and profitability of ICE when using pistons with a thermal insulation coating. Corundum layer of aluminum oxide is obtained by galvanic plasma treatment of standard engines' pistons.

Analysis of approaches to PEO silumin pistons application shows the possibility of treatment these materials in galvanostatic mode and with pulse current. In this case, in the regime of direct current, the «healing» of defects in oxide coatings and the formation of a surface with a more uniform morphology are observed [27]

\section{Methods of research}

The morphology of formed oxide layers surface was studied using a scanning electron microscope ZEISS EVO 40XVP (Germany).

Surface topography was studied by atomic force microscopy using the NT-206 microscope, CSC-37 probe (Belarus).

The chemical composition of the surface oxide layers was determined using an Oxford INCA Energy 350 energy dispersive spectrometer (UK) with an integrated SmartSEM software environment.

The catalytic activity of the coatings formed on the piston was analyzed during bench tests during combustion and catalytic conversion of toxic substances in the cylinder of the internal combustion engine. For this purpose, the coating was directly formed on the piston coating of a single-cylinder naturally aspirated diesel engine. The studies were carried out on a single-cylinder diesel engine of $12 / 14$ dimension with a piston of a standard design and with a piston with catalytic coating applied at loading speeds at a crankshaft rotation speed of $n=1200$ and $1400 \mathrm{rpm}$.

\section{Research results}

6.1. Plasma-electrolytic treatment of AK12M2MgN piston alloy. During the plasma-electrolytic treatment of the silumin, the voltage chronogram of the oxidation process have a classic shape with separation into the pre-spark, spark, micro-arc and arc regions [14, 22]. At the same time, the main technological parameters of PEO depend on the type of used electrolyte (Table 3 ).

Table 3

Technological parameters of plasma-electrolytic treatment of a piston alloy

\begin{tabular}{|c|c|c|c|c|}
\hline \multirow{2}{*}{ Electrolyte } & $\begin{array}{c}\text { Density of treat- } \\
\text { ment current, } \\
\text { A/dm }\end{array}$ & \multicolumn{2}{|c|}{ Voltage, B } & \multirow{2}{*}{$\begin{array}{c}\text { Treatment } \\
\text { time, min }\end{array}$} \\
\cline { 3 - 4 } & $3 \ldots 5$ & $115 \ldots 120$ & $140 \ldots 160$ & \multirow{2}{*}{$30 \ldots 60$} \\
\hline 2 & $15 \ldots 20$ & $150 \ldots 170$ & $220 . .240$ & \\
\hline
\end{tabular}

Oxidizing samples of the piston alloy AK12M2MgN in alkaline electrolyte solutions 1 and 2 produced uniform oxide coatings with the content of cobalt or manganese. By successive oxidation in electrolytes 1 and 2, it is possible to obtain a mixed layer of manganese and cobalt oxides.

At the initial stage of PEO treatment, an alumina surface layer is formed, which contains a large number of inclusions of irregular shape (Fig. 3). 


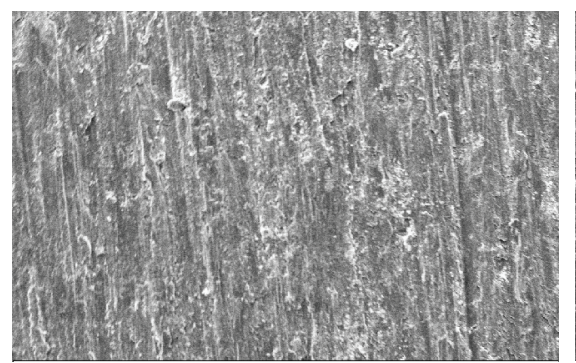

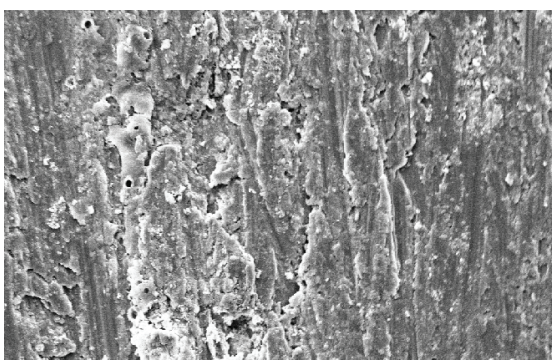

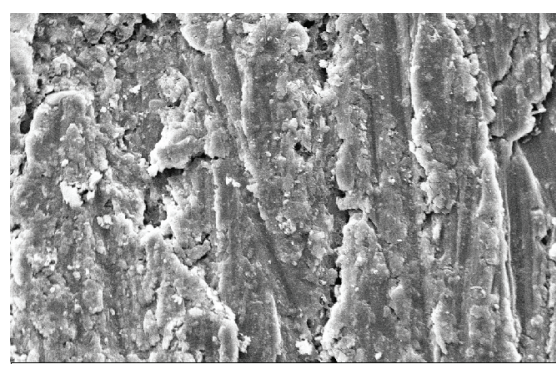

c

Fig. 3. Morphology of the surface $A K 12 M 2 M g N$, magnification: $a-\times 100 ; b-\times 500 ; c-\times 1000$

The morphology of mixed oxide coatings surface varies with the incorporation of doping metals into the alumina matrix.

Inclusion of cobalt occurs in the form of spheroid island structures of blue-violet color. In the progress of PEO treatment such mosaic structures evenly coats the whole surface of the sample. The cobalt content in the surface oxide layers reaches 24 at \% (Fig. 4, $a$ ). PEO silumin in the manganese alkaline electrolyte produces a uniform brownblack oxide layer with manganese content up to 35 at \%. The surface of the coating is microglobular, with a significant number of conglomerates formed by a small spheroid visualized on it (Fig. 4, $b$ ). Two-stage oxidation with the formation of a mixed layer of cobalt and manganese oxides makes it possible to obtain a finely dispersed porous layer. The total content of dopant in the composition of the surface layers reaches $25-30$ at \% (Fig. 4, c).

The above analysis of the chemical composition of the formed ceramic oxide coatings proves the effectiveness of plasma-electrolytic treatment of silumin. The silicon content in the surface layers does not exceed 3 at. \%, which is one of the requirements for catalytically active materials.

The resulting oxide coatings have a high degree of surface development [39], which is confirmed by the results study of the surface layers topography using atomic force microscopy (Fig. 5).
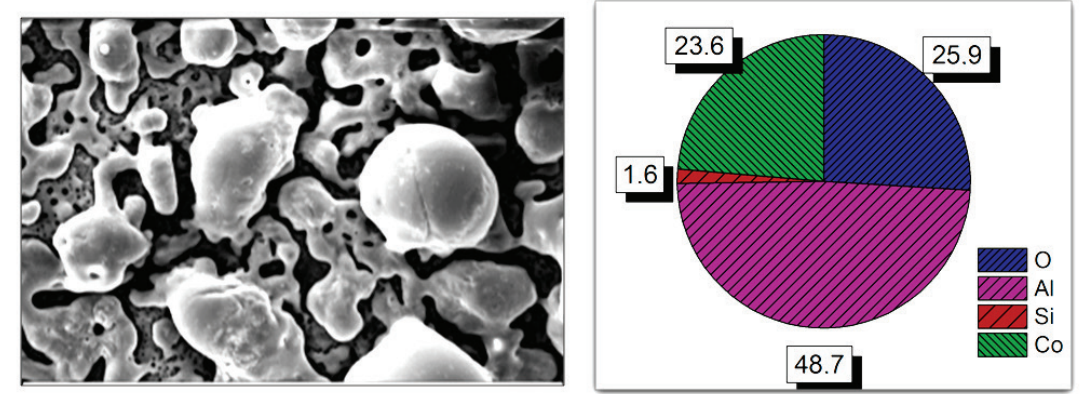

a
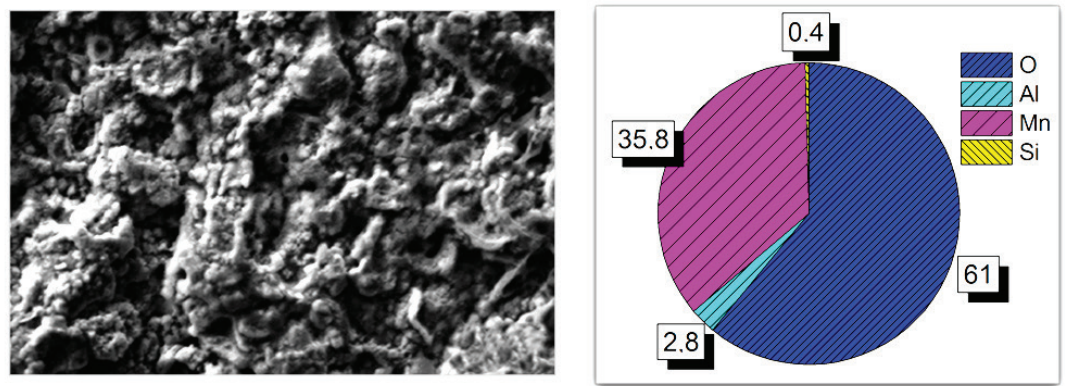

$b$
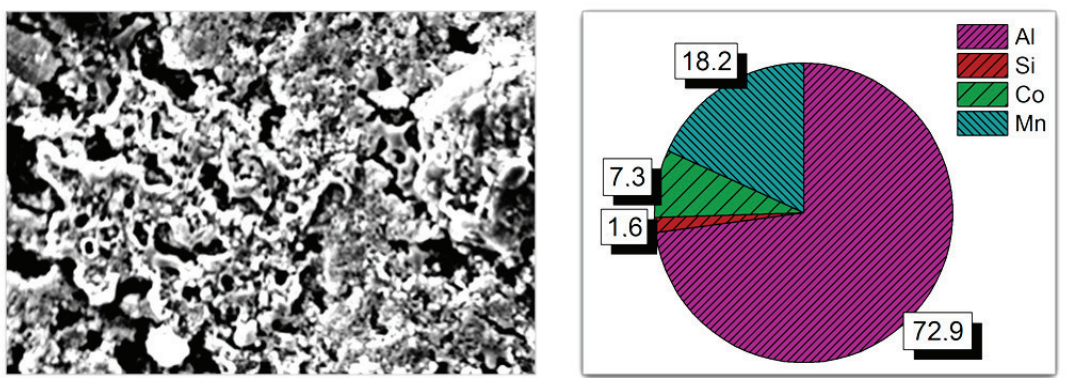

Fig. 4. Morphology and composition of oxide coatings on $\mathrm{AK} 12 \mathrm{M} 2 \mathrm{MgN}$, at \%: $a-\mathrm{Al}\left|\mathrm{Al}_{2} \mathrm{O}_{3} \cdot \mathrm{CoO}_{x} ; b-\mathrm{Al}\right| \mathrm{Al}_{2} \mathrm{O}_{3} \cdot \mathrm{MnO}_{y} ; c-\mathrm{Al} \mid \mathrm{Al}_{2} \mathrm{O}_{3} \cdot \mathrm{CoO}_{x}$, magnification $\times 1000$ 

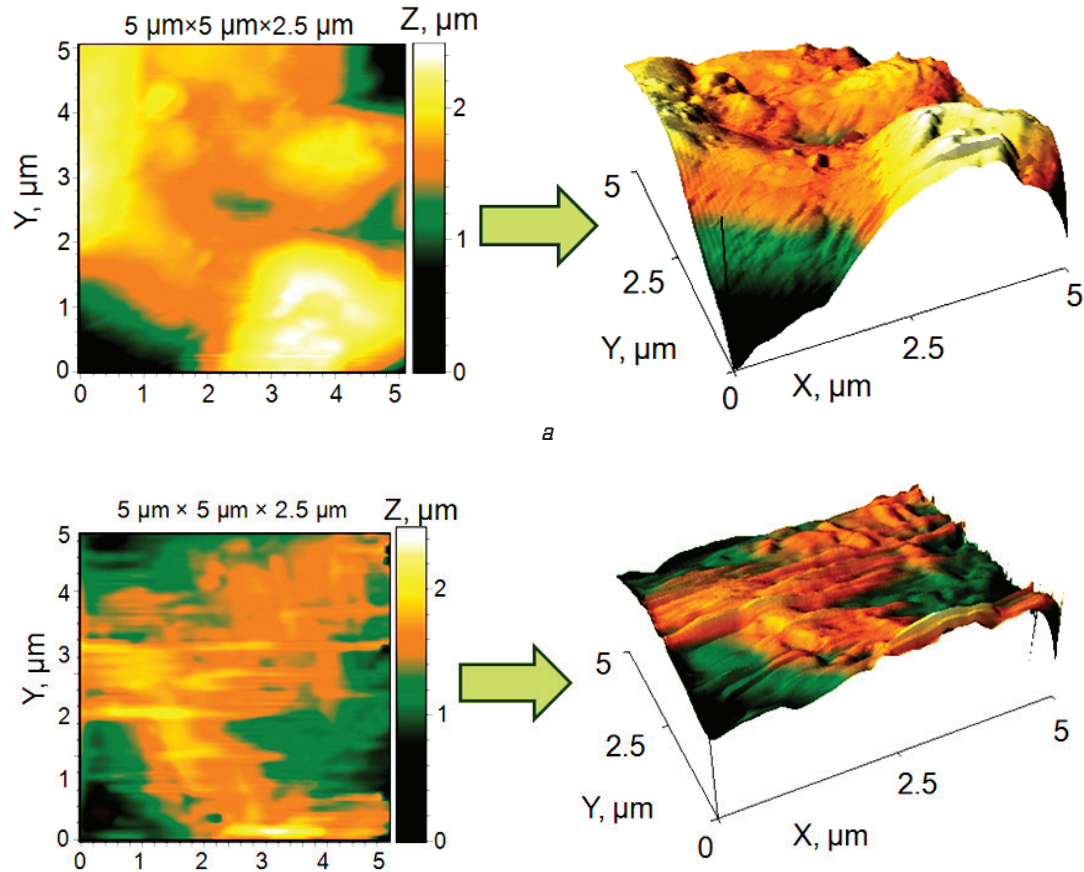

$b$

Fig. 5. 2-D- and 3-D-maps of the surface of oxide coatings on AK12M2MgN: $a-\mathrm{Al}\left|\mathrm{Al}_{2} \mathrm{O}_{3} \cdot \mathrm{CoO}_{x} ; b-\mathrm{Al}\right| \mathrm{Al}_{2} \mathrm{O}_{3} \cdot \mathrm{MnO}_{y}$. Scanning area $5 \times 5 \mu \mathrm{m}$

In general, the obtained results correlate with data for oxide PEO systems on aluminum alloys and other valve metals $[9,21]$.

In combination with a significant content of dopant in the oxide coating, a uniformly globular character and a high degree of surface development are prerequisites for high catalytic activity of the obtained systems [40].

Thus, the results of the carried out studies take into account the influence of the PEO parameters on the chemical composition and morphology of the surface of ceramic subabrasive coatings on the AK12M2MgN alloy.
Proceeding from this, the following technological parameters of the piston alloy treatment can be recommended to minimize the silicon content in the surface layers and incorporate the catalytically active components (Table 4).

Based on the research results analysis, optimal parameters of plasma electrolytic oxidation of piston silumin AK12M2MgN samples are determined, under which effective treatment of the alloy and the formation of ceramic-like coatings with a significant content of dopant are provided.

Recommended parameters of plasma-electrolytic treatment of silumin AK12M2MgN and the formation of doped cobalt and manganese ceramic coatings

\begin{tabular}{|c|c|c|c|}
\hline \multirow{2}{*}{ Parameter } & \multicolumn{3}{|c|}{ Coating } \\
\hline & $\mathrm{Al}_{2} \mathrm{O}_{3} \cdot \mathrm{CoO}_{x}$ & $\mathrm{Al}_{2} \mathrm{O}_{3} \cdot \mathrm{MnO}_{\mathrm{y}}$ & $\mathrm{Al}_{2} \mathrm{O}_{3} \cdot \mathrm{CoO}_{x}, \mathrm{MnO}_{y}$ \\
\hline Electrolyte composition, mol/dm ${ }^{3}$ & $\begin{array}{l}\mathrm{CaSO}_{4}-0.1 \\
\mathrm{~K}_{4} \mathrm{P}_{2} \mathrm{O}_{7}-0.4\end{array}$ & $\begin{array}{c}\mathrm{KMnO}_{4}-0.005 \\
\mathrm{KOH}-0.05\end{array}$ & $\begin{array}{l}\text { I stage: } \mathrm{CoSO}_{4}-0.1 ; \mathrm{K}_{4} \mathrm{P}_{2} \mathrm{D}_{7}-0.4 ; \\
\text { II stage: } \mathrm{KMnO}_{4}-0.005 ; \mathrm{K} \mathrm{H}-0.05\end{array}$ \\
\hline 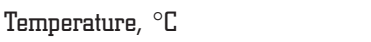 & \multicolumn{3}{|c|}{$20 \ldots .25$} \\
\hline Treatment mode & \multicolumn{3}{|c|}{ galvanostatic } \\
\hline Electric current density, $\mathrm{A} / \mathrm{dm}^{2}$ & $3 \ldots 5$ & $15 \ldots 20$ & $\begin{array}{l}\text { I stage }-3 \ldots 5 \\
\text { II stage }-15 \ldots .20\end{array}$ \\
\hline Voltage, V & $115 \ldots 160$ & $150 \ldots 240$ & $\begin{array}{l}\text { I stage }-115 \ldots 160 \\
\text { II stage }-220 \ldots 240\end{array}$ \\
\hline Treatment time, min & \multicolumn{3}{|c|}{$30 \ldots 60$} \\
\hline Content, at \% & up to 24.0 & up to 36.0 & $\begin{array}{l}\text { Co }- \text { up to } 10.0 \\
\text { Mn - up to } 19.0\end{array}$ \\
\hline Content, at. \% dopant silicon & up to 3.0 & up to 0.8 & up to 1.8 \\
\hline
\end{tabular}


6.2. The formation of ceramic oxide coatings on the piston coating of an internal combustion engine. Approbation of the possibility using the developed technology for plasmaelectrolytic treatment of ICE pistons was carried out by PEO of the piston of the KamAZ-740 engine (Ukraine) producing oxide coatings on the piston lid [19].

For treatment, a modernized laboratory facility with an electrolytic cell of the required size is used. Efficiently treatment of serial piston to form mixed oxides with cobalt and manganese (Fig. 6) is possible if using proposed technological parameters (Tables 2, 3).

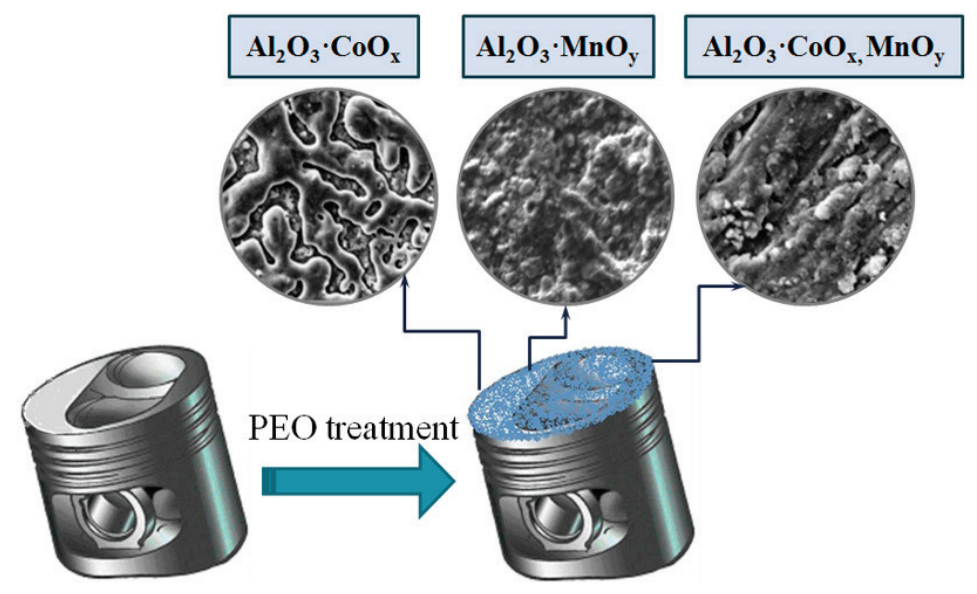

Fig. 6. Scheme representation of the surface of the KamAZ-740 piston (Ukraine) coated with mixed alumina with cobalt and/or manganese. Magnification $\times 1000$

To obtain coatings of sufficient quality, it is necessary to observe the temperature regime of formation and mixing of the electrolyte during oxidation.

6.3. Testing of catalytic activity of formed oxide coatings. Synthesized oxide coatings according to the results of testing in model reactions of $\mathrm{CO}$ and benzene oxidation are characterized by high catalytic activity and are not inferior to materials containing noble metals [20, 21].

The use of ceramic-like coatings on ICE piston leads to a decrease in the ignition temperature of the fuel mixture. Due to the thermal insulation properties of the catalytic coating layer, the consumption of air for all investigated oxide systems decreases compared to the unheated surface piston.

Due to the peculiarities of the processes of catalytic combustion of fuel in the near-wall zones of the combustion chamber of an internal combustion engine [41], the phase of uncontrolled combustion of fuel and the time of its combustion are reduced. A decrease in the hourly fuel consumption in the range of $1-4 \%$ is established. The highest fuel economy shows a piston with a ceramic like bottom layer containing nonstoichiometric manganese oxides.

The decrease in the combustion temperature excludes the possibility of the nitrogen participation in the gas phase reactions. These features of the combustion process and catalytic processes on the surface of the oxide coating of the piston ensure a reduction in the amount of toxic gas emissions of the engine.

The highest catalytic effect is shown by mixed oxide systems with cobalt. The piston with the coating of
$\mathrm{Al}_{2} \mathrm{O}_{3} \cdot \mathrm{CoO}_{x}$ allows to reduce $\mathrm{NO}_{x}$ emissions within $10 \%$ and $\mathrm{CO}-15-18 \%$, whereas for manganese-containing oxide coatings these values are much lower. This difference is due to the different affinity of cobalt and manganese in oxygen, as well as the differentiation of the thermal stability of the corresponding nonstoichiometric oxides.

Thus, the PEO treatment of the ICE pistons makes it possible to form manganese and cobalt containing ceramic like coatings with high catalytic properties.

These systems can find application in intra cylindrical catalysis technologies in order to reduce the toxicity of engine emissions and increase their fuel economy.

\section{SWOT analysis of research results}

Strengths. Among the strengths of this research, it is necessary to note the obtained results on the generalization of the influence of the main parameters of the technological process on the formation of ceramic like coatings doped with additional components. A positive factor is the use of non-toxic working solutions for the surface treatment of aluminumsilicon alloys.

Application of the developed technological parameters makes it possible to carry out effective surface treatment of piston alloys with a decrease in the silicon content to 3 at \% and the formation of oxide coatings with the content of manganese and cobalt.

Weaknesses. The weaknesses of this research are related to the need to use monitoring systems and maintain technological parameters of the plasma-electrolytic treatment in these intervals. Non-compliance with the recommended parameters can be one of the reasons for poor-quality treatment and a decrease in the content of catalytically active components in the coatings. At the same time, the technological process, which occurs at high voltages, requires certain safety measures from the working staff.

Opportunities. Opportunities for further research are related to the adaptation of the proposed technology to the treatment of other structural materials, as well as the expansion of the range of doping metals. This will improve the efficiency and expand the scope of use of mixed oxide systems.

The introduction of the proposed technical solution for treatment of ICE serial pistons will significantly improve fuel efficiency and engine life, reduce the amount of toxic gas emissions.

Threats. The difficulty in using the obtained results can be related to several factors. Firstly, this is the quality of the processed structural material and reagents for the preparation of working solutions. Secondly, the need to equip the technological site with modern equipment. Preference should be given to mobile multifunctional systems with the function of programming and automation of the technological process.

Additional costs of the company when implementing the proposed technical solution will be related to the purchase of certified materials, the modernization of existing sites of galvanic treatment and the upgrading of the skills of working personnel. 


\section{Conclusions}

1. We established the features of the influence of the main parameters of plasma-electrolytic treatment piston made of silumin AK12M2MgN in alkaline electrolytes containing manganese and cobalt compounds. One-step oxidation of silumin in a regime of incident power is proposed for the formation of ceramic like coatings doped with manganese or cobalt oxides.

2. The effect of dopant metals on the morphology and composition of surface oxide layers is studied. The ceramic like layers are uniform and have a developed surface. The content of dopant (cobalt and manganese) is up to $30 \ldots 36$ at \%, content of silicon does not exceed 3.0 at \%.

3. Based on model studies, the technology of plasmaelectrolytic treatment of the serial KamAZ-740 piston with the formation of the ceramic like coating on the combustion chamber is developed.

4. PEO treatment of ICE pistons allows the formation of manganese and cobalt containing ceramic like coatings with high catalytic properties. Manganese-containing oxide system demonstrate the highest fuel economy at 3-4\%. When using a piston with a cobalt oxides coating, toxic gas emissions are reduced: $\mathrm{NO}_{x}$ within $10 \%$ and $\mathrm{CO}-$ 15-18\%. The proposed systems can find application in intra cylindrical catalysis technologies in order to reduce the toxicity of gas emissions of engines and increase their fuel efficiency.

\section{References}

1. Belov N. A. Fazovyy sostav promyshlennykh i perspektivnykh alyuminievykh splavov: monograph. Moscow: Izdatelskiy dom MISiS, 2010. $511 \mathrm{p}$.

2. Glazoff M. V., Zolotorevsky V. S., Belov N. A. Casting Aluminum Alloys. Oxford: Elsiever, 2007. 544 p. doi:10.1016/ b978-0-08-045370-5.x5001-9

3. Resursozaoshchadzhuval'na tekhnolohiya vidnovlennya znoshenykh detaley / Sakhnenko M. D. et al. // Intehrovani tekhnolohiyi ta resursozberezhennya. 2013. Vol. 2. P. 9-13.

4. Kolmykov D. V., Honcharov A. N. Kombynyrovannye metody uprochnenyia // Visnyk Sumskoho natsionalnoho ahrarnoho universytetu. 2012. Vol. 6 (24). P. 46-50.

5. Mazurenko Ye. A., Herasymchuk A. I., Ovsiannykov V. P. Khimichne osadzhennia z hazovoi fazy, syntez funktsionalnykh materialiv (ohliad) // Fizyka i khimiia tverdoho tila. 2001 Vol. 2, No. 3. P. 339-349.

6. Thermal spraying of cylinder bores with the Plasma Transferred Wire Arc process / Bobzin K. et al. // Surface and Coatings Technology. 2008. Vol. 202, No. 18. P. 4438-4443. doi:10.1016/j.surfcoat.2008.04.023

7. Obzor tehnologicheskih meropriyatiy, napravlennyih na povyishenie nadezhnosti tsilindro-porshnevoy gruppyi dvigatelya vnutrennego sgoraniya / Nosov A. S. et al. // Sovremennyie materialyi, tehnika i tehnologii. 2017. Vol. 3 (11). P. 80-85.

8. Okada A. Innovative materials for automotive industry. New York: Nova Science Publishers, 2010. 147 p.

9. A study of synthesis and properties of manganese-containing oxide coatings on alloy VT1-0 / Sakhnenko N. et al. // EasternEuropean Journal of Enterprise Technologies. 2016. Vol. 3, No. 5 (81). P. 37-43. doi:10.15587/1729-4061.2016.69390

10. Mixed alumina and cobalt containing plasma electrolytic oxide coatings / Yar-Mukhamedova G. Sh. et al. // IOP Conference Series: Materials Science and Engineering. 2017. Vol. 213. doi:10.1088/1757-899x/213/1/012020

11. Povyishenie resursa rabotyi porshney dvigateley vnutrennego sgoraniya / Nemenenok B. M. et al. // Lite i metallurgiya. 2005. Vol. 2 (34). P. 175-178.

12. Aluminum- and titanium-supported plasma electrolytic multicomponent coatings with magnetic, catalytic, biocide or biocompatible properties / Rudnev V. S. et al. // Surface and
Coatings Technology. 2016. Vol. 307. P. 1219-1235. doi:10.1016/ j.surfcoat.2016.07.060

13. Electroplating and functional properties of Fe-Mo and Fe-Mo-W coatings / Ved M. V. et al. // Voprosyi himii i himicheskoy tehnologii. 2014. Vol. 5-6 (98). P. 53-60.

14. Electrolytic plasma technology: Science and engineering-An overview / Gupta P. et al. // Surface and Coatings Technology. 2007. Vol. 201, No. 21. P. 8746-8760. doi:10.1016/ j.surfcoat.2006.11.023

15. Rogov A. B., Slonova A. I., Shayapov V. R. Peculiarities of iron-containing microplasma coating deposition on aluminum in homogeneous electrolyte // Applied Surface Science. 2012. Vol. 261. P. 647-652. doi:10.1016/j.apsusc.2012.08.075

16. Microarc oxidation in slurry electrolytes: A review / Borisov A. M. et al. // Surface Engineering and Applied Electrochemistry. 2016. Vol. 52, No. 1. P. 50-78. doi:10.3103 s106837551601004x

17. Malyshev V. N., Zorin K. M. Features of microarc oxidation coatings formation technology in slurry electrolytes // Applied Surface Science. 2007. Vol. 254, No. 5. P. 1511-1516. doi:10.1016/j.apsusc.2007.07.079

18. Examining the formation and properties of $\mathrm{TiO} 2$ oxide coatings with metals of iron triad / Sakhnenko M. et al. // EasternEuropean Journal of Enterprise Technologies. 2017. Vol. 2, No. 11 (86). P. 4-10. doi:10.15587/1729-4061.2017.97550

19. Improving the environmental performance of engines by intracylinder neutralization of toxic exhaust gases / Parsadanov I. V. et al. // Internal Combustion Engines. 2016. No. 2. P. 63-67. doi:10.20998/0419-8719.2016.2.12

20. Functional mixed cobalt and aluminum oxide coatings for environmental safety / Ved M. V. et al. // Functional Materials. 2017. Vol. 24, No. 2. P. 303-310. doi:10.15407/fm24.02.303

21. Formation of coatings of mixed aluminum and manganese oxides on the AL25 alloy / Sakhnenko N. D. et al. // Surface Engineering and Applied Electrochemistry. 2016. Vol. 52, No. 2. P. 145-151. doi:10.3103/s1068375516020113

22. Kotok V., Kovalenko V., Malyshev V. Comparison of oxygen evolution parameters on different types of nickel hydroxide // Eastern-European Journal of Enterprise Technologies. 2017. Vol. 5 No. 12 (89). P. 12-19. doi:10.15587/1729-4061.2017.109770

23. Xu F., Xia Y., Li G. The mechanism of PEO process on Al-Si alloys with the bulk primary silicon // Applied Surface Science. 2009. Vol. 255, No. 23. P. 9531-9538. doi:10.1016/ j.apsusc.2009.07.090

24. Ceramic coating formation on high $\mathrm{Si}$ containing $\mathrm{Al}$ alloy by PEO process / Wang P. et al. // Surface Engineering. 2016 Vol. 32, No. 6. P. 428-434. doi:10.1179/1743294415y.0000000003

25. Dudareva N. Y., Abramova M. M. The Structure of PlasmaElectrolytic Coating Formed on $\mathrm{Al}-\mathrm{Si}$ alloys by the MicroArc Oxidation Method // Protection of Metals and Physical Chemistry of Surfaces. 2016. Vol. 52, No. 1. P. 128-132. doi:10.1134/s2070205116010093

26. Preparation of anti-corrosion films by microarc oxidation on an Al-Si alloy / Xue W. et al. // Applied Surface Science. 2007. Vol. 253, No. 14. P. 6118-6124. doi:10.1016/j.apsusc.2007.01.018

27. Anti-corrosion and wear properties of plasma electrolytic oxidation coating formed on high $\mathrm{Si}$ content $\mathrm{Al}$ alloy by sectionalized oxidation mode / Dai L. et al. // IOP Conference Series: Materials Science and Engineering. 2017. Vol. 167. P. 012063. doi:10.1088/1757-899x/167/1/012063

28. Rogov A. B. Plasma electrolytic oxidation of A1050 aluminium alloy in homogeneous silicate-alkaline electrolytes with edta 4-complexes of $\mathrm{Fe}, \mathrm{Co}, \mathrm{Ni}, \mathrm{Cu}, \mathrm{La}$ and $\mathrm{Ba}$ under alternating polarization conditions // Materials Chemistry and Physics. 2015 Vol. 167. P. 136-144. doi:10.1016/j.matchemphys.2015.10.020

29. On Composition of Anodic-Spark Coatings Formed on Aluminum Alloys in Electrolytes with Polyphosphate Complexes of Metals / Boguta D. L. et al. // Russian Journal of Applied Chemistry. 2002. Vol. 75, No. 10. P. 1605-1608. doi:10.1023/a:1022263331315

30. Rudnev V. S. Multiphase anodic layers and prospects of their application. Protection of Metals. 2008. Vol. 44, No. 3. P. 263-272. doi:10.1134/s0033173208030089

31. O primenenii tehnologii mikrodugovogo oksidirovaniya dlya remonta i vosstanovleniya izdeliy iz siluminov / Krishtal M. M. et al. // Aviatsionnaya i raketno-kosmicheskaya tehnika. 2012 Vol. 3 (34). P. 225-228. 
32. Krishtal M. M., Ivashin P. V., Kolomiets P. V. Ispolzovanie tehnologii mikrodugovogo oksidirovaniya pri razrabotke DVS s blokom tsilindrov iz alyuminievogo splava // Izvestiya Samarskogo nauchnogo tsentra Rossiyskoy akademii nauk. 2012. Vol. 12, No. 4. P. 242-246.

33. Experimentally Studied Thermal Piston-head State of the Internal-Combustion Engine with a Thermal Layer Formed by Micro-Arc Oxidation Method / Dudareva N. et al. // Science and Education of the Bauman MSTU. 2015. Vol. 15, No. 5. P. 115-125. doi:10.7463/0515.0774148

34. Butusov I., Dudareva N. Influence of micro-arc oxidation on durability of IC-engine's piston // Science and Education of the Bauman MSTU. 2013. Vol. 13, No. 9. P. 127-144. doi:10.7463/0913.0606017

35. Stepanov V. A. Uluchshenie ekspluatatsionnyih pokazateley avtomobiley mikrodugovyim oksidirovaniem dnisch porshney dvigateley // Science and world. 2014. Vol. 1 (5). P. 115-117.

36. Povyishenie tehniko-ekspluatatsionnyih pokazateley DVS modernizatsiey tsilindroporshnevoy gruppyi / Nurutdinov A. Sh. et al. // Vestnik SGAU im. N. I. Vavilova. 2013. Vol. 11 P. $56-59$.

37. Marchenko A. P., Shpakovskiy V. V. Vliyanie korundovogo sloya na rabochih poverhnostyah porshney na protsess sgoraniya v DVS // Dvigateli vnutrennego sgoraniva. 2011. Vol. 2. P. 24-28.

38. Marchenko A. P., Shpakovskyi V. V., Pylov V. V. Pidvyshchennya ekonomichnosti benzynovoho dvyhuna na riznykh rezhymakh roboty pry zastosuvanni chastkovo-dynamichnoyi teploizolyatsiyi porshniv // Visnyk NTU »KhPI». 2013. Vol. 32 (1005). P. $106-110$.

39. Sakhnenko N. D. Ved M. V. Karakurkchi A V. Chapter 38 . Nanoscale Oxide PEO Coatings Forming from Diphosphate Electrolytes: Proceedings / ed. by Fesenko O., Yatsenko L. // Nanophysics, Nanomaterials, Interface Studies, and Applications. Springer International Publishing AG, 2017. P. 507-531. doi:10.1007/978-3-319-56422-7 38

40. Synthesis of Catalytic Cobalt-Containing Coatings on Alloy Al25 Surface by Plasma Electrolytic Oxidation / Ved M. V. et al. // Chemistry, Physics and Technology of Surface. 2017. Vol. 82, No. 1. P. 73-79. doi:10.15407/hftp08.01.073

41. Increasing the efficiency of intra-cylinder catalysis in diesel engines / Parsadanov I. V. et al. // Voprosyi himii i himicheskoy tehnologii. 2017. Vol. 52, No. 6. P. 145-151.

\section{ИССЛЕДОВАНИЕ ОСОБЕННОСТИ ПЛАЗМЕННО- ЭЛЕКТРОЛИТИЧЕСКОЙ ОБРАБОТКИ ПОРШНЕВОГО СЛЛАВА АК12М2МГН С ФОРМИРОВАНИЕМ КЕРАМИКОПОДОБНЫХ ПОКРЫТИЙ}

Исследованы особенности плазменно-электролитической обработки (ПЭО) поршневого силумина АК12М2МгН в щелочных электролитах с формированием допированных марганцем и кобальтом керамикоподобных оксидных покрытий. Показано, что морфология и состав оксидных покрытий зависит от типа используемого электролита. Предложены технологические параметры ПЭО-обработки поршневого силумина для формирования равномерных покрытий с высоким содержанием допантов. Предложенные системы могут найти применение в технологиях внутрицилиндрового катализа для снижения токсичности газовых выбросов двигателей и повышения их топливной экономичности.

Һлючевые слова: поршневой сплав АК12М2МгН, плазменноэлектролитическое оксидирование, поршневой силумин, керамическое оксидное покрытие.

Karakurkchi Ann, PhD, Head of the Research Laboratory, National Technical University «Kharkiv Polytechnic Institute», Ukraine, e-mail: anyutikukr@gmail.com, ORCID: http://orcid.org/0000-00021287-3859

Sakhnenko Mykola, Doctor of Technical Sciences, Professor, Head of the Department of Physical Chemistry, National Technical University «Kharkiv Polytechnic Institute»,Ukraine, e-mail: sakhnenko@kpi.kharkov.ua, ORCID: http://orcid.org/0000-0002-5525-9525

Ved Maryna, Doctor of Technical Sciences, Professor, Department of General and Inorganic Chemistry, National Technical University «Kharkiv Polytechnic Institute», Ukraine, e-mail: vmv@kpi.kharkov.ua, ORCID: http://orcid.org/0000-0001-5719-6284

Parsadanov Igor, Doctor of Technical Sciences, Professor, Department of Internal Combustion Engines, National Technical University «Kharkiv Polytechnic Institute»,Ukraine, e-mail: parsadanov@kpi.kharkov.ua, ORCID: http://orcid.org/0000-0003-0587-4033 